\title{
An Analysis of the Determinants of Maize Import Volumes in Kenya
}

\author{
Maurine Adhiambo Abodi*, Isaac Maina Kariuki, Gideon Aiko Obare \\ Department of Agricultural Economics and Agribusiness Management, Egerton University, Egerton, Kenya \\ Email: ^maurineabodi@gmail.com, ikariuki@egerton.ac.ke, obarega@egerton.ac.ke
}

How to cite this paper: Abodi, M. A., Kariuki, I. M., \& Obare, G. A. (2021). An Analysis of the Determinants of Maize Import Volumes in Kenya. Theoretical Economics Letters, 11, 320-337. https://doi.org/10.4236/tel.2021.112022

Received: March 5, 2021

Accepted: April 13, 2021

Published: April 16, 2021

Copyright (อ 2021 by author(s) and Scientific Research Publishing Inc. This work is licensed under the Creative Commons Attribution International License (CC BY 4.0).

http://creativecommons.org/licenses/by/4.0/ (c) (i) Open Access

\begin{abstract}
The objective of our study is to investigate the key factors that determine maize import volumes in Kenya. To achieve this objective, we used time series secondary data from FAOSTAT, World Bank and World Trade Organization (WTO) for the period 1963 to 2016. We consider this period to be long enough to allow us to accurately capture the domestic maize price patterns before and after the onset of maize market reforms in Kenya. Our econometric analysis of the time series data using an error correction version of Autoregressive distributed lag model shows that maize import volume is determined by trade openness, domestic price of maize and gross domestic product in the long run. In the short run, the results show that maize import volume is determined by exchange rate, lag of exchange rate, lag of maize import volume and production. The findings suggest that to reduce overreliance on maize imports, effective management of macroeconomic environment should be stimulated to create a favourable environment for improving domestic maize production so as to discourage a surge in maize imports and at the same time improve the country's food security.
\end{abstract}

\section{Keywords}

Import, Maize, Autoregressive Distributed Lag Model, Kenya

\section{Introduction}

The importance of international trade in the process of development has for a long time been a topic of interest to international economists in both developed and developing economies (Fatukasi and Awomuse, 2011). Specifically, the study on determinants of imports has attracted the attention of many researchers in most developed and some developing economies (Yue and Constant, 2010; Abidin et al., 2016; Pablo and Yomar, 2019). As in many African countries, the eco- 
nomic development of Kenya is closely tied to the behaviour of international trade (Akyüz and Gore, 2001). In regards to this, the attractiveness of globalization, liberalization and interdependence between countries has also increased a great deal. This is evidenced by the rapid pace at which every country strives to achieve economic growth and development by attaining as much benefits from international trade as possible (Dao, 2016).

The reduction of global trade restrictions through globalization and World Trade Organization (WTO) commitments has also seen many developing countries import both agricultural and non-agricultural commodities from other parts of the world (Khan and Hussain, 2011). For instance, according to FAO (2017), world maize imports totalled to US $\$ 32.3$ billion in 2016. In Sub-Saharan Africa, about $30 \%$ of maize consumed in the region is imported compared to $5 \%$ in late sixties (FAO, 2017).

Kenyan economy is not an exception as it relies on many international economies for maize imports to boost her food security status. Besides importing electronics and other intermediate commodities, Kenya relies on other world economies to increase her strategic grain reserves (Gallagher, 2005). According to KNBS (2018), maize imports to Kenya increased more than eight fold to 1.328 million metric tonnes from 2016 to 2017 . This was necessitated by a $6.3 \%$ reduction in maize production from 3.402 million metric tonnes in 2016 to 3.186 million metric tonnes in 2017. Additionally, Kenya increased her maize imports from Uganda as grain prices rose due to destruction of harvests by El Nino rains in 2016. Kenya also received 3000 tonnes of maize in 2017 from Uganda through her border points (KNBS, 2018). The increase in maize imports in Kenya in the recent past has been experienced with the removal of price and quantity barriers on imports (Chapoto and Jayne, 2009). However, prior to the structural adjustment program (SAP) era Kenya's maize import volumes followed a downward trend since the country was self-sufficient in maize production (Swamy, 1994). In fact, in the 1960s and 1970s, Kenya was nearly net exporter of maize (Byerlee and Eicher, 1997).

Figure 1 shows the trend in domestic maize production and imports from 1963 to 2016. The figure shows that domestic maize production peaked during mid1970 s and early 1980s due to the existence of an enabling environment for private producer participation in farming after independence (Argwings-Kodhek et al., 1993). Consequently, there was a slight decline in the production between 1978 and 1980 a situation which could be attributed to inefficiencies in maize marketing and limited use of new technologies which was a disincentive to maize producers. Additionally, even though there was a modest growth in domestic maize production in the period between 1993 and 1995, this was followed by a steady decline in domestic maize production from 1995 to 2005 due to abating terms of trade between agricultural exports and imports and poor implementation of policies of trade (Jayne et al., 2008). This paved way for a sharp increase in maize imports between 1998 and 2001 primarily due to maize market reforms 


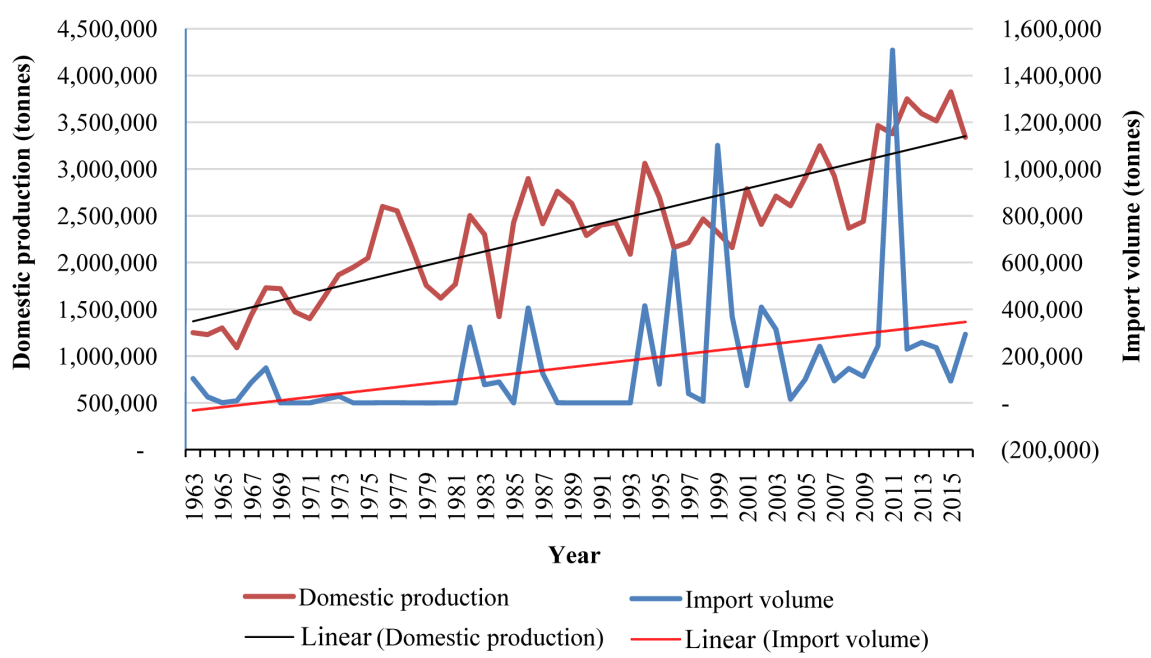

Figure 1. Trend in domestic production and maize imports (Source: FAOSTAT).

which culminated into the liberalization of the maize marketing system (Nyoro et al., 1999).

The decline in domestic maize production from 2007 to 2009 came as a result of political instability caused by post-election violence during this period. This saw a tremendous increase in maize imports from 2008 to 2012 to remedy the situation created by decreased domestic maize production. However, the value of maize imports is highly understated due to large informal imports which have not yet been documented. The trend in domestic maize production and maize imports confirms that over the years Kenya has been pursuing a policy of selfreliance on maize imports instead of self-sufficiency in maize production. Besides, Figure 1 shows that Kenya was only self-sufficient for a short period of time, that is, from 1963 to 1982 . The question that arises therefore is that, apart from production, are there other factors that drive maize importation?

The above trend in maize imports and production reveals that it is vital to know both the macroeconomic and microeconomic factors that drive maize importation in Kenya. This will inform policy decisions on strategies that the country should use to reduce her overreliance on maize imports and at the same time ensure food security in the country is guaranteed. However, despite the fact that studies on determinants of import have been done in many developed and developing countries, there is a limited empirical evidence of such studies in Kenya. Therefore, our study is a fresh attempt to model the determinants of aggregate maize import volumes in Kenya based on time series secondary data from 1963 to 2016. We also aim to propose policy options based on our findings for the control of maize imports in Kenya.

The rest of this article has been organised as follows: In the second section we present literature review. The third section addresses the methodological approach. In the fourth section we present results and discussions. Finally, in the fifth section we conclude and discuss policy recommendations. 


\section{Literature Review}

In this section we provide a stock of past and recent empirical works that have been done on determinants of imports in various countries using different types of variables and models. For instance, in a study done by Dao (2016) on the analysis of the determinants of share of imports in an economy based on data from World Bank, linear regression was performed on various samples from both developed and developing economies. A statistical model of the share of imports in the GDP was specified as being nonlinear and dependent on the gross national income and its square. The findings of the study revealed that empirical results vary depending on time period under consideration and the level of economic development in a country. However, this study was not devoid of a methodological weakness since estimation was based on level variables which could have led to a high possibility of inconsistent results based on spurious regressions.

In another study by Yue and Constant (2010) that aimed at ascertaining the key determinants of disaggregated import demand in Cote d'Ivore, time series data ranging from 1970 to 2007 were used in an ARDL modelling process so as to capture the effect of final consumption expenditure, export expenditure, investment expenditure and relative prices on imports. The study found a long run relationship among the variables. Additionally, inelastic import demand for all expenditure components and relative prices was found. However, in the short run, the study found other expenditure components to be the major determinants of import demand.

In a similar study on determinants of demand functions for imports in Nigeria, Fatukasi and Awomuse (2011) used real GDP, external reserves, real exchange rates and index of openness as explanatory variables. The error correction model results revealed that the error correction term was statistically significant indicating an existence of a long run relationship between the quantity of import demanded and its determinants over the sample period between 1970 and 2008. The study also established that real gross domestic product was a chief determinant of import demand in Nigeria in the short run. These findings corroborates the results of Egwaikhide (1999) who examined the determinants of imports in Nigeria using dynamic specification and error correction modelling and discovered that relative prices, foreign exchange earnings and real output were the significant determinants of the growth of total imports during the period under investigation.

In another study in Latin America that aimed at determining the behaviour of imports in Colombia for the period between 2000 and 2016, Pablo and Yomar (2019) established an existence of a long run relationship between real gross domestic product and real exchange rate with the import demand using an error correction model. The findings indicated that Colombian imports are determined by the gross domestic product and real exchange rate. Similar to this study, Keum and Lee (2017) employed first difference model and simultaneous equa- 
tion model with GMM estimation technique to estimate the determinants of intermediate goods imports and raw material goods imports respectively. They observed that the imports of final goods are determined by the importing country's income while the raw material goods imports are determined by an increase in exports in Korea. These results were further corroborated by Fedoseeva and Zeidan (2018) who also did a study on determinants of imports and observed that income was a major determinant of import demand in Europe.

On the same vein, using double logarithmic model and time series data spanning from 1961 to 2013, Hyuha et al. (2017) analysed the determinants of rice import demand in Uganda. With the study aimed at ascertaining the key parameters influencing rice import demand, the regression results revealed that domestic rice production, population and own rice consumption significantly influenced rice import demand. The study therefore recommended that there is need to reduce the rapid population growth rate and increase domestic production for the country to save her foreign exchange. In a similar study on determinants of aggregate import demand in Sudan, Ibrahim and Ahmed (2017) used data spanning from 1978 to 2014 and cointegration techniques to analyse the data. Their findings revealed that volume of imports, domestic income, relative prices and exchange rate were the significant determinants of aggregate import demand. The magnitude of the coefficient of GDP was higher than the other determinants hence suggesting that GDP was the most important factor that influenced the aggregate import demand in Sudan.

In another study that investigated how supply shocks, both domestic and foreign, impacted imports and consumption in the world rice market between 1960 and 2010, Jha et al. (2016) established that domestic shocks had a significant positive influence on volume of imports in a country. The authors concluded that no matter the nature of foreign shocks, the primary concern should be to stabilize consumption when an economy is faced by negative domestic shock such as a rise in domestic prices. Unlike the study by Ozturk (2012) which found that foreign exchange was an important factor that influenced volume of imports in an economy, the study by Jha et al. (2016) indicated that it was less significant.

From the empirical studies above, it is evident that empirical results continue to fuel debate in the sense that there exist wide variations on the determinants of imports. The literature review shows no consensus on the determinants of imports. Some studies identify gross domestic product and exchange rate as the major determinants of imports while others focus on consumption, prices and population as major determinants of imports. This lack of consensus encourages further analysis in this area especially in Kenya where such studies are rare. In addition to income and exchange rate, our study adds domestic price, trade openness and consumption as explanatory variables in an analysis of the determinants of maize import volumes. Following the works of Narayan and Narayan (2005); Pablo and Yomar (2019); Keum and Lee (2017); Fedoseeva and Zeidan (2018), we use an error correction version of ARDL model which captures time 
series properties of unit roots and the existence of long run relationship to analyse the determinants of maize import volumes. The exchange rate and gross domestic product are included in this model in order to capture the effect of macroeconomic variables on volume of maize imports and to eliminate the aggregation bias. This differs from traditional import models which use only import and relative prices as components of the import function. Hence, our study extends the works of Egwaikhide (1999) and Dao (2016). We assume that maize import demand equals to actual volume of imports.

\section{Methodology}

This section is divided into three parts: in the first part the sources of data are described. Secondly, the variables used in the analysis are described. Finally, modelling strategy is described in detail.

\subsection{Data Sources}

We used data from secondary sources to generate 54 year annual time series data on maize import quantities, domestic prices, maize production, maize consumption, gross domestic product, exchange rate and trade openness for the period between 1963 and 2016. We obtained the data from both international and domestic sources. International sources included FAOSTAT and World Bank online data sources. On the other hand, domestic sources consisted of publications from Kenya National Bureau of Statistics (statistical abstracts and economic survey documents).

\subsection{Description of Variables}

Import (Maize import volume) is used as a dependent variable. We assume that it is determined by trade openness, domestic production of maize, domestic consumption of maize, domestic price, gross domestic product and exchange rate. It is used as a continuous variable measured in tonnes. The use of import volume as a dependent variable is justified by past empirical studies (e.g., Yue and Constant, 2010; Fatukasi and Awomuse, 2011).

Opens (openness index) is used as a proxy for trade openness. It is the summation of exports and imports normalised by gross domestic product. It measures a country's exposure to international trade. This variable is measured as the sum of exports plus imports, divided by gross domestic product. We anticipated that the more a country opens up for trade, the more it imports. It is used as a continuous variable and its expected sign is positive. The use of this variable as an explanatory variable is justified by past empirical studies (e.g., Fatukasi and Awomuse, 2011).

Prod and Cons are used as proxies for domestic production and domestic consumption respectively. We postulated that the lower the domestic maize production, the higher the demand for maize for consumption to meet the deficit created by the low domestic output, hence the need for maize imports. These 
two variables are continuous and are measured in tonnes. The inclusion of these two variables as explanatory variables is justified by past empirical studies (e.g., Khan and Hussain, 2011).

$D p$ and $G d p$ represents domestic price of maize and gross domestic product respectively. We expected domestic price to have a positive effect on maize imports since we postulated that the higher the maize domestic price, the higher the maize imports. Consequently, we used gross domestic product to assess the effect of macroeconomic environment on maize imports. We expected the relationship between gross domestic product and maize imports to be negative. A study by Abidin et al. (2016) confirmed the use of these variables as explanatory variables in the analysis of determinants of maize import volumes.

Similarly, Exr (exchange rate) is also used to assess the effect of macroeconomic environment on maize imports. An unfavourable exchange rate (when local currency is weaker than the foreign currency) is anticipated to have a negative impact on maize imports. Additionally, an appreciation of Kenya shillings against a foreign currency is anticipated to have a positive effect on maize imports. The use of this variable as an explanatory variable is justified by past empirical studies (e.g., Hyuha et al., 2017).

In order to normalize the skewed original data and linearize both dependent and independent variables; we transformed all the variables into logarithms except exchange rate and openness index so as to allow maize import volume to respond proportionately to all its determinants as well as to boost the validity of our analysis.

\subsection{Modelling Strategy}

We used ADF test to check for stationarity or the problem of unit root and the integration order of the series. A stationary series is a series with a constant variance and mean in its level form denoted by I (0) while a non-stationary series is a series with a mean and a variance which are time variant (Wooldridge, 2013). A non-stationary series can be made stationary by taking the first or second difference of the series denoted by I (1) and I (2) (Gujarati, 2003). Therefore, following Wooldridge (2013), we performed ADF test using the functional form 1 .

$$
\Delta Z_{t}=\alpha_{1}+\alpha_{2 t}+\beta Z_{t-1}+\sum_{t=1}^{n} \delta \Delta Z_{t-1}+e_{t}
$$

where $\Delta$ is the change operator, $Z_{t}$ is variable in the series to be checked for stationarity, $Z_{t-1}$ is one period lagged values, $\Delta Z_{t-1}$ shows the first difference and $e_{t}$ is the white noise error term. The decision rule is that if the ADF test statistic is higher than the critical value in absolute terms at $5 \%$ significance level, then the series is stationary. On the other hand, if the ADF test statistic is lower than the critical value in absolute terms at $5 \%$ significance level, then the series is non-stationary or it has a unit root problem in which case it should be differenced to make it stationary (Gujarati, 2003). 
Secondly, we used bounds test for cointegration to check the existence of long run relationship among the variables. The decision rule is that if the F statistic value is greater than the upper bound value at $5 \%$ significance level, then there exists a long run relationship among the variables. On the other hand, if the $\mathrm{F}$ statistic is lower than the upper bound value then there is no long run relationship among the variables. We tested the existence of long run relationship under the null hypothesis of no cointegration.

Thirdly, the existence of long run relationship (cointegration) led us to the estimation of both short and long run parameters using the error correction version of ARDL model. Following Pesaran and Shin (1999), we chose this model due to its ability to provide more choices in selecting optimal lag numbers (Yeshineh, 2017). Another reason why we used this model is its ability to produce unbiased results in small and finite samples. Given a sample size of 54 that we used, the model was deemed to produce consistent and reliable results both on theoretical and empirical grounds. Therefore, due to the evidence of long run relationship, we specified ARDL model equation as seen in Equation (2).

$$
\begin{aligned}
\ln \text { import }_{t}= & \alpha_{1}+\sum_{j=1}^{n} \beta_{1} \Delta \text { opens }_{t-1}+\sum_{j=1}^{n} \beta_{2} \Delta \ln \operatorname{prod}_{t-1}+\sum_{j=1}^{n} \beta_{3} \Delta \ln \text { cons }_{t-1} \\
& +\sum_{j=1}^{n} \beta_{4} \Delta \ln d p_{t-1}+\sum_{j=1}^{n} \beta_{5} \Delta \ln g d p_{t-1}+\sum_{j=1}^{n} \beta_{6} \Delta \operatorname{exr}_{t-1}+u_{t}
\end{aligned}
$$

where $t$ is the time period, $\theta$ represents the long run elasticities, $\alpha_{1}$ is a constant and $u_{t}$ is the white noise error term.

Finally, we specified the error correction version of the ARDL model to facilitate the analysis of the long run and short-run effects of the explanatory variables on import volumes and to suggest the speed of adjustment to long-run equilibrium (Yeshineh, 2017).

$$
\begin{aligned}
\ln \text { import }_{t}= & \alpha_{1}+\sum_{j=1}^{n} \beta_{1} \Delta \text { opens }_{t-1}+\sum_{j=1}^{n} \beta_{2} \Delta \ln \operatorname{prod}_{t-1}+\sum_{j=1}^{n} \beta_{3} \Delta \ln \text { cons }_{t-1} \\
& +\sum_{j=1}^{n} \beta_{4} \Delta \ln d p_{t-1}+\sum_{j=1}^{n} \beta_{5} \Delta \ln g d p_{t-1}+\sum_{j=1}^{n} \beta_{6} \Delta \operatorname{exr_{t-1}}+\gamma E C T_{t-1}+e_{t}
\end{aligned}
$$

where $\beta$ shows short run elasticities and $E C T_{t-1}$ is the error correction term which is a measure of the adjustment speed to long run equilibrium after a shock and ranges from -1 to 0 . The error correction model term is the most consistent determinant of imports (Fedoseeva and Zeidan, 2018). It warrants the safety of the series and ensures that the long run equilibrium is achievable by correcting errors in one period by the next (Pablo and Yomar, 2019). Zero indicates that there is no convergence to equilibrium while the negative value shows that a shock in the system is perfectly adjusted to equilibrium in the next period. $\gamma$ is the parameter of the speed of adjustment.

\section{Results and Discussion}

In this section, we first present and discuss diagnostic test results, followed by 
long run and short run results. Finally, a discussion on post estimation diagnostic tests is given.

\subsection{Diagnostic Test Results}

Table 1 presents the ADF test results for the level variables. The results indicate that maize import volume (lnimports) has no unit root meaning that it is stationary. On the other hand, openness index, production, consumption, domestic price, GDP and exchange rate were found to be non-stationary in level form.

Table 2 presents the ADF test results for differenced variables. The results show that openness index, production, consumption, domestic price, GDP and exchange rate become stationary after first differencing. This implies that they are all integrated of order I (1). The ADF test results for the level and differenced variables suggest a mixture of stationarity among the variables therefore justifying the suitability of the error correction version of ARDL model in this analysis due to its ability to produce feasible results when the data set in question contains both exogenous and endogenous variables which are integrated of order I (0) and I (1). The ADF test results are in corroboration with the findings of Egwaikhide (1999); Abidin et al. (2016); Pablo and Yomar (2019) who found a mixture of I (0) and I (1) in an analysis of determinants of imports in different countries.

We also performed ARDL bounds test to investigate the presence of long run relationship among the variables. Table 3 presents bounds test results. It reveals

Table 1. ADF test results for level variables.

\begin{tabular}{cccc}
\hline Series & Test statistic & Critical value & Inference \\
\hline lnimports & -3.044 & -2.928 & Stationary \\
Openness index & -0.917 & -2.929 & Non stationary \\
lnproduction & -2.160 & -2.930 & Non stationary \\
lnconsumption & -1.655 & -2.928 & Non stationary \\
lndomestic price & -0.461 & -2.928 & Non stationary \\
lnGDP & -1.623 & -2.928 & Non stationary \\
Exchange rate & 0.578 & -2.928 & Non stationary
\end{tabular}

Table 2. ADF test for differenced variables.

\begin{tabular}{cccl}
\hline Series & Test statistic & Critical value & Inference \\
\hline Openness index & -6.484 & -2.930 & Stationary \\
lnproduction & -5.475 & -2.933 & Stationary \\
Inconsumption & -6.661 & -2.929 & Stationary \\
Lndomestic price & -6.705 & -2.929 & Stationary \\
lngdp & -4.714 & -2.929 & Stationary \\
Exchange rate & -4.688 & -2.929 & Stationary
\end{tabular}


Table 3. Bounds test for long run relationship.

\begin{tabular}{ccc}
\hline Test statistic & Lower bound I(0) & Upper bound I(1) \\
\hline F-statistic 4.409 & 2.714 & 4.125 \\
t-statistic -4.621 & -2.857 & -4.413 \\
\hline
\end{tabular}

the existence of a long run relationship among the variables since the F statistic value is greater than the upper bound value at $5 \%$ significance level. This result is further confirmed by the $\mathrm{t}$-statistic value which is less than the upper bound value at 5\% significance level. This is in line with the findings of Carone (1996); Tang and Nair (2002); Tang (2003); Razafimahefa and Hamori (2005); Narayan and Narayan (2005); Pablo and Yomar (2019) who also found long run relationship between the import and its determinants.

\subsection{Long Run Results on Determinants of Maize Import Volumes}

Table 4 is a presentation of the long run results on determinants of maize import volumes. The results reveal that the openness index is positive and significant at $10 \%$ significance level as was expected. This suggests that a 1 unit increase in trade openness is associated with $23.364 \%$ point increase in maize import volumes, holding other factors constant. A possible reason for this is that the more an economy opens for trade, the more the influence of trade on her domestic activities and the more it imports. This is consistent with the findings of Fatukasi and Awomuse (2011) who found a positive relationship between import and trade openness.

The coefficient of maize domestic price is $4.242 \%$ which is elastic and significant at $10 \%$ significance level signifying that a $1 \%$ increase in domestic maize price results into $4.242 \%$ increase in volume of maize imports, holding other factors constant. This could be attributed to the fact that Kenya does not produce many viable alternatives to her imported maize. Therefore, Kenya is heavily reliant on imported maize for which there exist a few domestic substitutes. This suggests that exchange rate policy can be used to influence maize imports in Kenya. This result is similar to the findings of Egwailkide (1999) who in his analysis of import demand determinants in Nigeria established that import demand is price elastic. However, this result is contrary to the findings of Sinha (1997) and Yue and Constant (2010) who established that aggregate import demand is price inelastic in the long run and is not sensitive to price changes. Additionally, the result is different from the findings of Khan and Hussain (2011) who established a negative relationship between domestic price and imports. Unlike the current study which indicates that maize imports in Kenya can be significantly controlled using domestic price, the study by Khan and Hussain (2011) shows that tea imports in Parkistan cannot be significantly controlled by adjusting the domestic price. This was so because Parkistan is the largest importer of tea and only negligible part of tea consumed in the country is produced 
Table 4. Long run results on determinants of maize import volumes.

\begin{tabular}{cccc}
\hline Series & Coefficient & Std. Err. & Probability \\
\hline Openness index & 23.364 & 13.499 & $0.093^{*}$ \\
Inproduction & -3.581 & 6.596 & 0.591 \\
lnconsumption & 0.346 & 1.535 & 0.823 \\
Indomestic price & 4.242 & 2.427 & $0.090^{\star}$ \\
lnGDP & -10.515 & 5.577 & $0.068^{*}$ \\
Exchange rate & -0.038 & 0.077 & 0.629 \\
\hline
\end{tabular}

${ }^{\star}$ represents significance at $10 \%$ significance level.

locally. Therefore, the country has to import tea regardless of changes in local tea prices. Hence, changes in domestic prices are not likely to affect tea imports.

The coefficient of GDP (gross domestic product) is negative and significant implying that a $1 \%$ increase in GDP leads to $10.515 \%$ decrease in volume of maize imports, other factors held constant. This result has an implication that an improvement in maize domestic production would lead to a decrease in volume of maize imports. This could be attributed to the fact that the purchase of domestic goods and services increases GDP and therefore an increase in GDP means an increase in domestic production. Secondly, this could be attributed to GDP increase shifting demand away from maize as a staple food to more luxurious food stuff like wheat. Thirdly, since GDP is a development indicator, this may also indicate that the more a country develops, the more it diversifies its domestic production by producing other commodities or products through research and extension services which may act as substitutes for maize, thereby decreasing maize imports.

Finally, another implication of the negative coefficient of GDP is the fact that international trade is a large and growing component of GDP. Nevertheless, this does not mean that trade reduces domestic output and growth but rather that import variable corrects imports that are already in consumption, private investment and government expenditure hence the negative elasticity. This result confirms the findings of Pablo and Yomar (2019) who established that imports are determined by GDP and exchange rate in Colombia. This result also validates the findings of Agbola and Damoense (2005) who found that GDP, relative prices and urbanisation are the key determinants of import demand for pulses in India in the long run. However, the result contrasts findings of Fatukasi and Awomuse (2011); Khan and Hussain (2011) who established a positive relationship between imports and GDP.

\subsection{Short Run Results on Determinants of Import Volumes}

Table 5 presents the short run results on determinants of maize import volumes. In the short run all variables are significant according to priori expectations except openness index. However, domestic price and consumption do not have 
Table 5. Short run results on determinants of maize import volumes.

\begin{tabular}{|c|c|c|c|}
\hline Variable & Coefficient & Std. error & Probability \\
\hline Speed of adjustment & -0.704 & 0.148 & $0.000^{* * *}$ \\
\hline Dlnimports $(-1)$ & 0.411 & 0.144 & $0.007^{* * *}$ \\
\hline Dopenness & -11.102 & 8.358 & 0.193 \\
\hline Dlnopenness $(-1)$ & -9.107 & 6.657 & 0.181 \\
\hline Dlnproduction & 1.323 & 3.524 & 0.710 \\
\hline Dlnproduction $(-1)$ & 7.838 & 2.753 & $0.008^{\star * *}$ \\
\hline Dexchange rate & -0.175 & 0.078 & $0.032^{* *}$ \\
\hline Dexchange rate $(-1)$ & 0.173 & 0.087 & $0.057^{\star}$ \\
\hline Constant & 4.504 & 0.348 & 0.002 \\
\hline \multicolumn{3}{|c|}{$\mathrm{R}^{2}$} & 0.8232 \\
\hline \multicolumn{3}{|c|}{ Adjusted $\mathrm{R}^{2}$} & 0.7293 \\
\hline \multicolumn{3}{|c|}{ Jarque-Berra statistic probability value } & 0.3335 \\
\hline \multicolumn{3}{|c|}{ Durbin Watson statistics } & 2.0267 \\
\hline \multicolumn{3}{|c|}{ Breusch-Godfrey LM test probability value } & 0.8716 \\
\hline \multicolumn{3}{|c|}{ White's test probability value } & 0.4334 \\
\hline \multicolumn{3}{|c|}{ Cameron and Trivedi's decomposition of IM-test probability value } & 0.4263 \\
\hline
\end{tabular}

Note $^{* * *},{ }^{* *},{ }^{*}$ represents significance at $1 \%, 5 \%$, and $10 \%$ respectively.

any effect on import volume in the short run. The coefficient of the error correction term which represents the speed of adjustment is -0.704 which is negative and significant at $1 \%$ significance level validating the error correction version of ARDL model. The speed of adjustment measures the speed at which import volume adjusts to changes in its determinants before converging to its normal equilibrium level. It also broadly reflects the relative importance attached to the various import policies by authorities. These results are in corroboration with the previous findings of Narayan and Narayan (2005) who found a speed of adjustment of -0.76 which was negative and significant. The speed of adjustment of -0.704 is very close to that of -0.72 which was found by Frimpong and Oteng-Abayie (2006) in an investigation of aggregate import demand for maize and expenditure components in Ghana. However, the result supersedes the findings of Fatukasi and Awomuse (2011) who found a significant but very low speed of adjustment of -0.07 . Therefore, our model performed very well both on theoretical and empirical basis.

The first lag of imports (Dlnimports $(-1)$ ) is positive and significant at $1 \%$ significance level with a coefficient of 0.411 implying that a $1 \%$ increase in maize imports in the previous period leads to a $0.411 \%$ increase in volume of maize imports in the current period, holding other factors constant. This finding suggests that initially, imports remain steady in the short term since contract for importation of maize has already been signed in the previous period and it has 
to be fulfilled. Secondly, this could be attributed to the fact that maize importers and the government have a forward looking behaviour hence their previous period's decision on the volume of maize imports may have an influence on the volume of maize imports in the current period. For instance, when domestic maize price increase persists, maize importers may decide to increase the volume of maize imports in the current period to take advantage of the available market opportunity by bringing in cheap maize imports.

The first lag of domestic production (lnproduction $(-1)$ ) is positive and significant at $1 \%$ significance level in the short run. This implies that a $1 \%$ increase in maize production in the previous period leads to $7.838 \%$ increase in maize imports in the current period, other factors held constant. A basic reason for this is that maize importers follow their demand programmes in such a way that maize demand always matches real maize import volumes or levels. However, in several occasions, volume of maize imports fail to instantly adjust to long term equilibrium level with regards to changes in its determining factors or explanatory variables. Numerous factors may contribute to this. Key among these factors is the cost of adjustment, constraints in capital markets, inertia and lags or habit in observing the changes. Hence, an increase in maize production in the previous period may not warrant a corresponding instant decrease in maize imports in the current period. This finding agrees with the results of Narayan and Narayan (2005).

Similarly, current exchange rate (Dexchange rate) and first lag of exchange rate (Dexchange rate $(-1)$ ) are significant at $5 \%$ and $10 \%$ significance levels respectively. The coefficient of the current exchange rate is negative and significant an indication that the higher the exchange rate, the lower the volume of maize imports. This could be ascribed to the period when a dollar strengthens against the Kenya shilling thus making it more expensive to import than to export. Another reason could be that in the short term, depreciation may not be able to improve current account of the balance of payment. However, the first lag of exchange rate is positive and significant indicating that a 1 unit increase in exchange rate in the previous period leads to $0.173 \%$ increase in volume of maize imports in the current period, holding other factors constant. This could be accredited to the appreciation or strengthening of Kenya shilling against a dollar in the previous period which lowers the prices of imported staples and other durables in the current period. The reduced import prices thus lower importation cost and inflation rate hence enabling the Kenyan government and private traders to import more. Consequently, this shows that depreciation of US dollar results in a significant and proportionate increase in Kenyan imports. This confirms the vulnerability of Kenyan economy to the exogenous shocks. This agrees with the findings of Bensafta (2018) in Algerian study.

\subsection{Post Estimation Diagnostic Test Results}

We carried out Residual analysis on the estimated regressions to ensure the va- 
lidity of the results for policy suggestions. We followed this by doing post estimation diagnostic tests to establish the conformity of the time series variables to the assumptions of homoscedasticity, normality and serial correlation. JarqueBera normality test $(\mathrm{p}=0.3335)$ is statistically insignificant. Therefore, we accepted the null hypothesis of normality. We used the Durbin Watson (DW) test to test for serial correlation. The DW statistic of $d=2.0267$ shows that we accept the null hypothesis of no serial correlation. We further validated the DW test result by the Breusch-Pagan LM test for autocorrelation which shows that $\mathrm{p}=$ 0.8716 indicating that there is no autocorrelation. We used White's test to test for heteroscedasticity. We obtained a probability value of 0.4334 which shows that we accept the null hypothesis that the errors are homoscedastic. We further confirmed this by Cameron and Trivedi's decomposition of IM-test for heteroscedasticity which shows a probability value of $\mathrm{p}=0.4263$. Finally, the adjusted $R^{2}$ value of 0.7293 indicates that $72.93 \%$ of the variations in import volumes are explained by our model variables. Hence on the basis of this, we conclude that our model best fits the data and is well behaved.

\section{Conclusion and Recommendations}

We used a recently developed bounds testing approach to test for long run relationship between import, trade openness, production, consumption, domestic price of maize, GDP growth and exchange rate. The results confirm an existence of a long run relationship between the import equation variables when import volume is used as a dependent variable. This led to the estimation of both long and short run elasticities of the maize import equation using an error correction version of ARDL model. The key long run and short run results are that: trade openness, domestic production, maize domestic price, GDP and exchange rate are the key determinants of maize import volumes in Kenya. These results have plausible magnitude and are consistent both theoretically and empirically. On the basis of the results we can make the following conclusions:

Firstly, it is evident that domestic price plays a very crucial role in determining maize import volume. Therefore, inflation should be kept at auspicious levels through a sensible monetary policy of ensuring low and stable inflation so as to bring about price stability in the economy. This will ensure money supply in the economy is consistent with the growth and price objectives set by the government.

Secondly, GDP is negative and significant suggesting that even though GDP growth promotes international trade in the long run; it cannot frequently be a source of finance for maize imports. Import growth can possibly imply a multiplier effect on public expenditure which can be financed through external flows such as external aid through donor activities in Kenya and emigrant remittances. Therefore, economic strengthening should be encouraged to attract funds for investment from other countries without economic and political risk. Effective management of macroeconomic environment leading to economic growth should 
therefore be stimulated to create a favourable environment for improved maize production so as to discourage maize imports.

Thirdly, exchange rate is also a significant determinant of import volumes in Kenya. It therefore follows that the terms of trade should be put in check to ensure balance of payments and to rectify both internal and external imbalances. This will go hand in hand in reducing trade deficit once the exchange rate is favourable. Hence, the earnings from exports will be sufficient enough to compensate for higher spending on imports. This will contribute to improvement in foreign exchange earnings and ultimately to productivity improvement as a result of reduction in the import bill.

We recommend that a recipe to constraint overreliance on maize imports is not to lower production or to curtail demand. At the heart of the solution lies the need for acceleration of structural change in production. Therefore, the problem that the Kenyan economy needs to solve first is to improve or accelerate domestic production. In particular, Kenyan government should encourage improvement in domestic production of maize and other staples like cassava, millet, wheat and rice in order to diversify consumption of the staple and improve food security status of the economy. In doing so, the Kenyan economy needs to enhance an advanced technological production and boost her exports to internally compete with maize imports so as to reduce the surge of maize imports.

Further, to enhance the beneficial effect of the improved production technology, investment in research and development projects should be highly encouraged. Low production technology will only lead to overdependence on maize imports and encourage foreign trade deficit which is not safe for the economy. These results also point out that structural policies and exchange rate policies should be implemented so as to solve chronic foreign trade deficit problems in Kenya. In addition, policies designed to influence imports in particular must involve substantial domestic and adjustment efforts. The government's fiscal discipline must also be heartened to take care of the extensiveness in increase in maize importation so as to decrease the maize import bill.

Finally, this import volume model can be used in forecasting and is available for forecasting upon request. This research was a step towards finding import volume determinants for maize in Kenya and it provides a leeway for policy makers and regulators.

However, our study was deficient in the sense that the time series secondary data used in the analysis was inconsistent. For instance, the series on gross domestic product and domestic maize prices were recorded differently for the same year in different yearbooks. Therefore, a high frequency data should be published to allow future researchers on this topic to develop a more comprehensive, credible and reliable database to be used in analysis. Additionally, in this study, the only price determinant of maize import volume that we considered was domestic price of maize because of the limited data available on relative prices. Future research on this topic should consider relative prices of other sta- 
ples like wheat, rice, sorghum and cassava to produce more reliable and robust results.

\section{Conflicts of Interest}

The authors declare no conflict of interest with regards to the publication of this paper.

\section{References}

Abidin, I. S. Z., Haseeb, M., Chiat, L. W., \& Islam, M. R. (2016). Determinants of Malaysia-BRICS Trade Linkages: Gravity Model Approach. Investment Management \& Financial Innovations, 13, 389-398. https://doi.org/10.21511/imfi.13(2-2).2016.14

Agbola, F. W., \& Damoense, M. Y. (2005). Time-Series Estimation of Import Demand Functions for Pulses in India. Journal of Economic Studies, 32, 146-157. https://doi.org/10.1108/01443580510600922

Akyüz, Y., \& Gore, C. (2001). African Economic Development in a Comparative Perspective. Cambridge Journal of Economics, 25, 265-288. https://doi.org/10.1093/cje/25.3.265

Argwings-Kodhek, G., Mukumbu, M., \& Monke, E. A. (1993). The Impacts of Maize Market Liberalization in Kenya. Food Research Institute Studies, 22, 331-348.

Bensafta, K. M. (2018). US Dollar Dynamics and It impacts on Algeria Imports from the Eurozone (No. 2579). Orleans: Orleans Economics Laboratory, University of Orleans. https://hal.archives-ouvertes.fr/hal-01771863

Byerlee, D., \& Eicher, C. K. (Eds.) (1997). Africa’s Emerging Maize Revolution. Boulder, CO: Lynne Rienner Publishers.

Carone, G. (1996). Modeling the US Demand for Imports through Cointegration and Error Correction. Journal of Policy Modelling, 18, 1-48. https://doi.org/10.1016/0161-8938(95)00058-5

Chapoto, A., \& Jayne, T. S. (2009). The Impacts of Trade Barriers and Market Interventions on Maize Price Predictability: Evidence from Eastern and Southern Africa. Working Paper (No. 1096-2016-88338). East Lansing, MI: Michigan State University.

Dao, M. Q. (2016). Determinants of the Relative Importance of Imports in the Economy: An Empirical Assessment. British Journal of Economics, Management and Trade, 15, 1-18. https://doi.org/10.9734/BJEMT/2016/30839

Egwaikhide, F. O. (1999). Determinants of Imports in Nigeria: A Dynamic Specification. International Journal of Development Issues, 9, 167-187.

FAO (2017). The State of Food Security and Nutrition in the World: Building Resilience for Peace and Food Security. http://www.fao.org/3/a-i7695e.pdf

Fatukasi, B., \& Awomuse, B. O. (2011). Determinants of Import in Nigeria: Application of Error Correction Model. Centrepoint Journal, Humanities Edition, 14, 52-72.

Fedoseeva, S., \& Zeidan, R. (2018). How (a) Symmetric Is the Response of Import Demand to Changes in Its Determinants? Evidence from European Energy Imports. Energy Economics, 69, 379-394. https://doi.org/10.1016/j.eneco.2017.12.009

Frimpong, J. M., \& Oteng-Abayie, E. F. (2006). Aggregate Import Demand and Expenditure Components in Ghana: An Econometric Analysis. MPRA Paper, 599. https://mpra.ub.uni-muenchen.de/id/eprint/599

Gallagher, P. (2005). The First Ten Years of the WTO: 1995-2005. Cambridge: Cambridge 
University Press. https://doi.org/10.30875/dbbfd01d-en

Gujarati, D. N. (2003). Basic Econometrics (4th ed.). Singapura: McGraw-Hill.

Hyuha, T., William, E., \& Grace, B. K. (2017). Determinants of Import Demand of Rice in Uganda. International Journal of Applied and Pure Science and Agriculture, 3, 75-81. https://doi.org/10.22623/IJAPSA.2017.3010.FKL6W

Ibrahim, A. A. A., \& Ahmed, E. M. (2017). The Determinants of Aggregate Demand Function of Sudan. Business and Economics Journal, 8, 1-7.

Jayne, T. S., Myers, R. J., \& Nyoro, J. (2008). The Effects of NCPB Marketing Policies on Maize Market Prices in Kenya. Agricultural Economics, 38, 313-325. https://doi.org/10.1111/j.1574-0862.2008.00302.X

Jha, S., Kubo, K., \& Ramaswami, B. (2016). International Trade and Risk Sharing in the Global Rice Market: The Impact of Foreign and Domestic Supply Shocks. Asian Development Review, 33, 162-182. https://doi.org/10.1162/ADEV a 00064

Keum, H., \& Lee, S. (2017). Determinants of Different Types of Imports: Evidence from Korea. Journal of International Trade \& Commerce, 13, 87-106. https://ssrn.com/abstract $=3000278$ https://doi.org/10.16980/jitc.13.3.201706.87

Khan, R. E. A., \& Hussain, T. (2011). Import Elasticity of Tea: A Case of Pakistan. Interdisciplinary Journal of Contemporary Research in Business, 2, 308-314. https://ssrn.com/abstract=1969321

KNBS (2018). Economic Survey. Nairobi: Kenya National Bureau of Statistics. https://ecampus.kra.go.ke/info/National-International-Research-and-Policy/Kenya-Ec onomic-Survey-2018.pdf

Narayan, S., \& Narayan, P. K. (2005). An Empirical Analysis of Fiji's Import Demand Function. Journal of Economic Studies, 32, 158-168.

https://doi.org/10.1108/01443580510600931

Nyoro, J. K., Kiiru, M. W., \& Jayne, T. S. (1999). Evolution of Kenya's Maize Marketing Systems in the Post-Liberalization Era. 4th Agricultural Transformation Workshop, Nairobi, 27-30 June 1999, No. 680-2016-46751.

Öztürk, M. (2012). Macroeconomic Factors Affecting the Import in Turkey. Journal of QafQaz University, 34, 39-46.

Pablo, F. P. J., \& Yomar, V. D. J. (2019). Main Determinants of Imports in Colombia, 2000-2016. Revista Tendencias, $X X$, No 1(1er).

Razafimahefa, I. F., \& Hamori, S. (2005). Import Demand Function: Some Evidence from Madagascar and Mauritius. Journal of African Economies, 14, 411-434. https://doi.org/10.1093/jae/eji014

Sinha, D. (1997). Determinants of Import Demand in Thailand. International Economic Journal, 11, 73-873. https://doi.org/10.1080/10168739700000027

Swamy, G. (1994). Kenya: Structural Adjustment in the 1980s (Vol. 1238). London: World Bank Publications.

Tang, T. C. (2003). An Empirical Analysis of China's Aggregate Import Demand Function. China Economic Review, 14, 142-163. https://doi.org/10.1016/S1043-951X(03)00021-X

Tang, T. C., \& Nair, M. (2002). A Cointegration Analysis of Malaysian Import Demand Function: Reassessment from the Bounds Test. Applied Economics Letters, 9, 293-296. https://doi.org/10.1080/13504850110073471

Wooldridge, J. M. (2013). Introductory Econometrics: A Modern Approach. Mason, OH: South Western Cengage Learning. 
Yue, Y., \& Constant, N. (2010). An Econometric Estimation of Import Demand Function for Cote d'Ivoire. International Journal of Business and Management, 5, 77-78.

https://doi.org/10.5539/ijbm.v5n2p77 